\title{
Ternary Complexes of Cu (II), Ni (II), Co (II) and La (III) Ions with 2-[(Pyridin-2-Ylmethylidene) Amino] Phenol and Heterocyclic Nitrogen Base
}

\author{
Omyma A.M. Ali ${ }^{1 *}$, Samir M. El-Medani², Doaa A. Nassar ${ }^{3}$ \\ ${ }^{I}$ Chemistry Department, Faculty of Women for Arts, Science and Education, Ain Shams University, Cairo, \\ Egypt. \\ ${ }^{2}$ Chemistry Department, Faculty of Science, El-Faiyum University, El-Faiyum, Egypt
}

*Corresponding Author: Omyma A. M. Ali, Chemistry Department, Faculty of Women, Ain Shams University, Cairo, Egypt

\begin{abstract}
A new ternary Schiff base transition metal complexes of general formula $\left[M(H L)(2-A P) C_{2}\right] \cdot \mathrm{H}_{2} \mathrm{O}$ where $\mathrm{M}=\mathrm{Cu}(\mathrm{II}), \mathrm{Ni}(\mathrm{II})$ and $\mathrm{Co}(\mathrm{II})$ ions in addition to the complex $\left[\mathrm{La}(\mathrm{HL})(2-\mathrm{AP})\left(\mathrm{NO}_{3}\right)_{2}\right] . \mathrm{NO}_{3}$ have been prepared by template synthesis. The synthesized metal complexes were characterized using spectroscopic techniques. The molar conductivities of the complexes in DMF indicated non electrolytic behavior except La(III) complex.IR spectra show that the Schiff base (HL) is coordinated to the metal ions in a tridentate manner with NNO donor sites of the pyridine- $N$, azomethine- $N$ and phenolic-O, while 2-aminopyridine coordinated to the metal ions via its pyridine- $N$. The ligand $(H L)$ and its mixed ligand complexes exhibited intraligand $\left(\pi-\pi^{*}\right)$ fluorescence and can potentially serve as photoactive materials. The catalytic activity of the complexes towards hydrogen peroxide decomposition reaction was investigated. Both the ligand $(H L)$ and mixed ligand complexes have been screened for antibacterial activities.
\end{abstract}

Keywords: 2-Aminopyridine; Catalytic Activity; Fluorescence; Schiff Base.

\section{INTRODUCTION}

Schiff bases are one of the most prevalent and important of the mixed donor systems in the field of coordination chemistry.2-Aminopyridines also serve as useful chelating ligands in a variety of inorganic and organ metallic applications [1,2]. Amino pyridines and their derivatives in most cases act as monodentate ligands which coordinate the metal ions through the nitrogen of the ring $[3,4]$. Also, amino pyridines have been proposed as drugs for the treatment of many diseases such as myocardial infarction as antithrombus agents and diarrhea as antimicrobial agents $[5,6]$. Moreover, amino pyridines are commonly present in synthetic and natural products [7]. They form repeated moiety in many large molecules with interesting photophysical, electrochemical and catalytic applications [8].The complexes with different types of heterocyclic such asamines, imines, oxazole, imidazole and ligands containing pyridine play an important role in biology and medicine areas. These ligands are often used in medicine, because of their pharmacological properties such as antibacterial activity $[9,10]$.On the other hand, complexes of Schiff base ligands derived from 2pyridinecarboxaldehyde derivatives with some transition metals such as $\mathrm{Cu}(\mathrm{II}), \mathrm{Co}(\mathrm{II}), \mathrm{Cd}(\mathrm{II})$ and $\mathrm{Zn}$ (II) show significant biological activity [11,12]. Moreover, luminescent compounds are attracting much current research interest because of their many applications including emitting materials for organic light emitting diodes, light harvesting materials for photo catalysis and fluorescent sensors for organic or inorganic analytes [13-17]. The decomposition of hydrogen peroxide has been used as a model reaction for the investigation of the catalytic activity of various metal complexes [18]. For example, the catalytic activity of copper (II) complex of chitosan derivative which derived from chitosan and 4, 6-diacetylresorcinol was investigated on hydrogen peroxide decomposition [19]. Also, the mixed ligand complex $\left[\mathrm{Fe}(2-\mathrm{AP})(\mathrm{Ala}) \mathrm{Cl}_{3}\right] 4 \mathrm{H}_{2} \mathrm{O}(2-\mathrm{AP}=2$-acetylpyridine, $\mathrm{Ala}=$ alanine $)$ catalyzed the decomposition of $\mathrm{H}_{2} \mathrm{O}_{2}$ and $\mathrm{O}_{2}$ was evolved [20]. Herein, we report the transition metal complexes of Schiff base derived from the condensation of 2-pyridinecarboxaldehyde with 2aminophenol.The ternary complexes were obtained by reaction with 2 -aminopyridine. The structural features of these complexes were examined by analytical and spectral techniques. 


\section{EXPERIMENTAL}

\subsection{Materials and Reagents}

2-pyridinecarboxaldehyde, 2-aminophenol and 2-aminopyridine were supplied by Aldrich. All metal salts used in this investigation $\mathrm{CuCl}_{2} \cdot 2 \mathrm{H}_{2} \mathrm{O}, \mathrm{NiCl}_{2} \cdot 6 \mathrm{H}_{2} \mathrm{O}, \mathrm{CoCl}_{2} \cdot 6 \mathrm{H}_{2} \mathrm{O}$ and $\mathrm{La}\left(\mathrm{NO}_{3}\right)_{3} \cdot 6 \mathrm{H}_{2} \mathrm{O}$ were provided by Aldrich Chemicals. All solvents were of analytical grade and were purified by distillation before use.

\subsection{Instruments}

Infrared measurements using ( $\mathrm{KBr}$ pellets) were carried out on a Unicam-Mattson 1000 FT-IR spectrometer and magnetic measurements of the complexes in the solid state (Gouy method) were recorded on a Sherwood magnetic susceptibility balance. ${ }^{1} \mathrm{H}$ NMR measurements were performed on a Varian-Mercury $300 \mathrm{MHz}$ spectrometer. Elemental analyses for carbon, hydrogen, and nitrogen (CHN) were performed on a Perkin-Elmer 2400 CHN elemental analyzer. Mass spectrometry measurement of the solid complex was carried out on a JEOL JMS- AX 500 spectrometer. Thermo gravimetric analyses (TG and DTG) were carried out under $\mathrm{N}_{2}$ atmosphere with a heating rate of 10 ${ }^{\circ} \mathrm{C} / \mathrm{min}$. using a Shimadzu DT-50 thermal analyzer. All conductivity measurements were performed in DMF $\left(1 \times 10^{-3} \mathrm{M}\right)$ at $25^{\circ} \mathrm{C}$, by using Jenway 4010 conductivity meter. The Photo luminescent properties of all compounds were studied using a Jenway 6270 Fluorimeter.

\subsection{Synthesis of Schiff Base Hlligand}

A methanolic solution of 2-pyridinecarboxaldhyde $(0.9 \mathrm{~g}, 8.40 \mathrm{mmol})$ was added to a methanolic solution of 2-aminophenol $(0.91 \mathrm{~g}, 8.40 \mathrm{mmol})$ and refluxed for $\sim 11 \mathrm{~h}$ and kept overnight. The resulting solution was then concentrated by evaporation and then the orange precipitate was formed. The precipitate formed was filtered and recrystallized from hot methanol to pure compound.

\subsection{Synthesis of Mononuclear Mixed-Ligand Complexes}

To an ethanolic solution of themetal salt (Cu(II), Ni(II), $\mathrm{Co}(\mathrm{II})$ and $\mathrm{La}(\mathrm{III})$ a mixture of HLand 2aminopyridine (2-AP) in a mixed solvent of DMF-THF (1:2) were added slowly. The metals- ligands molar ratio was (1:1:1). The reaction mixtures were refluxed for 5-7 $\mathrm{h}$. The solid materials were filtered off and washed with ethanol and petroleum ether. The synthesized complex was dried at room temperature. Table 1 gives the elemental analysis and physical data for the complexes.

\subsection{Catalytic Activity}

The catalytic activity of the complexes has been evaluated by recording the rate of decomposition of hydrogen peroxide of known molarity prepared. The metal complex $\left(4.1 \times 10^{-3}-8.2 \times 10^{-3} \mathrm{mmol}\right)$ was mixed with $50 \mathrm{ml}$ of $\mathrm{H}_{2} \mathrm{O}_{2}(0.15 \mathrm{~N})$ in a flask under constant stirring at room temperature. Then, the extent of hydrogen peroxide decomposed at different intervals of time (each $30 \mathrm{~min}$; from 0 to $4.5 \mathrm{~h}$ ) was estimated by titrating $5 \mathrm{ml}$ aliquots of reaction mixture with $0.01 \mathrm{M} \mathrm{KMnO}_{4}$ in the presence of $0.01 \mathrm{M} \mathrm{H}_{2} \mathrm{SO}_{4}$. The difference in titer values of the $\mathrm{KMnO}_{4}$ solution before and after the catalyzed decomposition was recorded.

\subsection{Antibacterial Activity}

The in vitro antimicrobial activities of the free ligand and its complexes were tested against the bacteria: Staphylococcus aureus (gram +ve) and Escherichia coli (gram -ve) in Mueller Hinton-Agar medium. The standard disc diffusion method was followed to determine the antibacterial activity of the synthesized compounds. The well $(8 \mathrm{~mm}$ diameter) was then filled with the test solution and the plates were inoculated at $37^{\circ} \mathrm{C}$ for $48 \mathrm{~h}$. During this period, the growth of the inoculated microorganisms was affected and then the inhibition zones developed on the plates were measured. The effectiveness of an antibacterial agent was assessed by measuring the zones of inhibition around the well. The diameter of the zone is measured to the nearest millimeter $(\mathrm{mm})$. The antibacterial activity of each compound was compared with that of standard antibiotics such as Tetracycline. DMSO was used as a control under the same conditions for each organism and no activity was found. The activity results were calculated as a mean of triplicates.

\section{RESULTS AND DISCUSSION}

The reaction of Schiff-base ligand (HL) with $\mathrm{Cu}(\mathrm{II}), \mathrm{Ni}(\mathrm{II}), \mathrm{Co}(\mathrm{II})$ and $\mathrm{La}(\mathrm{III})$ ions in the presence of 2-aminopyridine produce the ternary complexes having the molecular formula as shown in Table 
1.The synthesized mixed ligand complexes were found to be air stable, moisture free and soluble onlyin DMF and DMSO. The course of the reactions may be as follows:

$$
\begin{aligned}
& \mathrm{HL}+2-\mathrm{AP}+\mathrm{MCl}_{2} \cdot \mathrm{nH}_{2} \mathrm{O} \longrightarrow\left[\mathrm{M}(\mathrm{HL})(2-\mathrm{AP}) \mathrm{Cl}_{2}\right] \cdot \mathrm{H}_{2} \mathrm{O}+\mathrm{xH}_{2} \mathrm{O} \\
& \mathrm{M}=\mathrm{Cu}(\mathrm{II}) ; \mathrm{n}=2 ; \mathrm{x}=1 \\
& \mathrm{Ni}(\mathrm{II}) \text { and } \mathrm{Co}(\mathrm{II}) ; \mathrm{n}=6 ; \mathrm{x}=5 \\
& \mathrm{HL}+2-\mathrm{AP}+\mathrm{La}\left(\mathrm{NO}_{3}\right)_{3} \cdot 6 \mathrm{H}_{2} \mathrm{O} \longrightarrow\left[\mathrm{La}(\mathrm{HL})(2-\mathrm{AP})\left(\mathrm{NO}_{3}\right)_{2}\right] \cdot \mathrm{NO}_{3}+6 \mathrm{H}_{2} \mathrm{O}
\end{aligned}
$$

\subsection{IR Spectra}

The IR spectral data of Schiff base [HL] and ternary complexes are presented in Table 2. The infrared spectrum of HL exhibited vibrational bands at 3387 and $1247 \mathrm{~cm}^{-1}$ due to $v(\mathrm{OH})$ and $v(\mathrm{C}-\mathrm{O})$ bonds. In addition, the IR spectrum of the HL displayed $v(C=N)$ at 1630 and $1590 \mathrm{~cm}^{-1}$ for both azomethine and pyridyl moieties, respectively. The IR spectra of the $\mathrm{Cu}(\mathrm{II}), \mathrm{Ni}(\mathrm{II}), \mathrm{Co}(\mathrm{II})$ and $\mathrm{La}(\mathrm{III})$ ternary complexes showed characteristic bands due to $\mathrm{OH}, \mathrm{C}-\mathrm{O}$ and $\mathrm{C}=\mathrm{N}$ function groups with the appropriate shifts due to complex formation.In addition,the IR-spectra of the ternary complexes containing 2-aminopyridine as a secondary ligand showed that the band characterizing the stretching vibration for $\mathrm{NH}_{2}$ group (occurring at 3447 and $3307 \mathrm{~cm}^{-1}$ ) overlapped with $\mathrm{OH}$ group. The two bands at $1501 \mathrm{~cm}^{-1}$ and $630 \mathrm{~cm}^{-1}$ characteristic to $v(\mathrm{C}=\mathrm{N})$ and $\delta(\mathrm{py})$ for 2-aminopyridine shifted in the complexes indicating the involvement of pyridine ring nitrogen in coordination and so, 2aminopyridine acts as a neutral monodentate ligand [21]. Interestingly, the in-plane ring deformation band of py in HL ligand is found at $625 \mathrm{~cm}^{-1}$. On complexation, this band of py shifted to higher frequencies, suggesting the coordination of pyridyl nitrogen to metal. Four intense bands in the spectrum of La(III) complex observed at 1445, 1034, 1311 and $818 \mathrm{~cm}^{-1}$. The separation frequency of $134 \mathrm{~cm}^{-1}$ between $1445\left(v_{\mathrm{s}}\right)$ and $1311\left(v_{\mathrm{as}}\right)$ is consistent with the value reported in literature for the nitrate group coordinates in a bidentate manner [22,23]. In addition, there is a band at $1384 \mathrm{~cm}^{-1}$ in the spectrum of the $\mathrm{La}(\mathrm{III})$ complex indicates that the existence of free nitrate group in the ionization sphere [24]. The presence of non-ligand bands in the spectra of complexes in the region 545-550 $\mathrm{cm}^{-1}$ and $410-451 \mathrm{~cm}^{-1}$ were assigned to $v(\mathrm{M}-\mathrm{O})$ and $v(\mathrm{M}-\mathrm{N})$ stretching vibrations, respectively [25].

\section{2. ${ }^{1} \mathrm{H}$ NMR Spectra}

Proton NMR spectrum of HL was compared with the diamagnetic mixed ligand La(III) complex in deuterated DMSO using TMS (tetramethylsilane) as internal standard. The ${ }^{1} \mathrm{H}$ NMR spectrumof the free Schiff base ligand HL showed signal at $10.09 \mathrm{ppm}$ attributed to theOH proton. The ${ }^{1} \mathrm{H}$ NMR spectrum of La(III) complex displayed a signal at $10.18 \mathrm{ppm}$ indicating the coordination of HL ligand to lanthanum atom through the hydroxyl group without deprotonation. The shifting of azomethine ($\mathrm{CH}=\mathrm{N}-)$ group in free ligand from $8.59 \mathrm{ppm}$ to $8.62 \mathrm{ppm}$ in the $\mathrm{La}(\mathrm{III})$ complex indicatesthatthe azomethine group is involved in the complexation. The chemical shifts of the different types of protons in the ${ }^{1} \mathrm{H}$ NMR spectra of the HL ligand and La(III) complex are listed in Table 3.

\subsection{Mass Spectra Analysis}

The mass spectrum of the ligand HLdisplayed the parent molecular ions $[\mathrm{M}]^{+}$at $\mathrm{m} / \mathrm{z}=198$, and important fragments at $52(35 \%)\left[\mathrm{C}_{4} \mathrm{H}_{4}\right]^{+}, 65(40 \%)\left[\mathrm{C}_{4} \mathrm{H}_{3} \mathrm{~N}\right]^{+}, 79(71 \%)\left[\mathrm{C}_{5} \mathrm{H}_{5} \mathrm{~N}\right]^{+}$and $93(19 \%)$ $\left[\mathrm{C}_{6} \mathrm{H}_{5} \mathrm{O}\right]^{+}$.

The mass spectrum of $\left[\mathrm{Cu}(\mathrm{HL})(2-\mathrm{AP}) \mathrm{Cl}_{2}\right] \cdot \mathrm{H}_{2} \mathrm{O}$ complex (Fig. 1) gave molecular ion peak at 445 (F.Wt. $=444.8)$. The spectrum exhibits a peak at 427(Calc.426.7) corresponding to the removal of hydrated water molecule. This fragment ion underwent fragmentation with loss of the two chlorine atoms gave a peak at 357.00 (Calc.355.8). Further fragmentation with loss of 2-AP ligand gave a peak at 261.00 (Calc. 261.76).

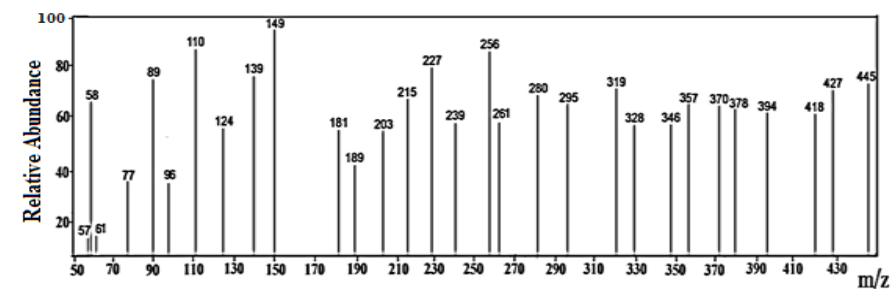

Figure1. The mass spectrum of $\left[\mathrm{Cu}(\mathrm{HL})\left(2-\mathrm{AP}^{\mathrm{C}} \mathrm{Cl}_{2}\right] \cdot \mathrm{H}_{2} \mathrm{O}\right.$ complex 
The Mass spectrum of [Co (HL) (2-AP) Cl2]. $\mathrm{H}_{2} \mathrm{O}$ complex (Fig. 2) observed a molecular ion peak at $440(\mathrm{~F} . \mathrm{Wt}=440.1)$. The existence of both primary and secondary ligands are indicated by the peaks at 197 and 94 (Calc.198.2 and 94.1), respectively. The removal of hydrated water molecule indicated by the peak at 421 (Calc.422.2). This fragment ion underwent fragmentation with the loss of the water molecule and two chlorine atoms gave a peak at 353 (351.27).

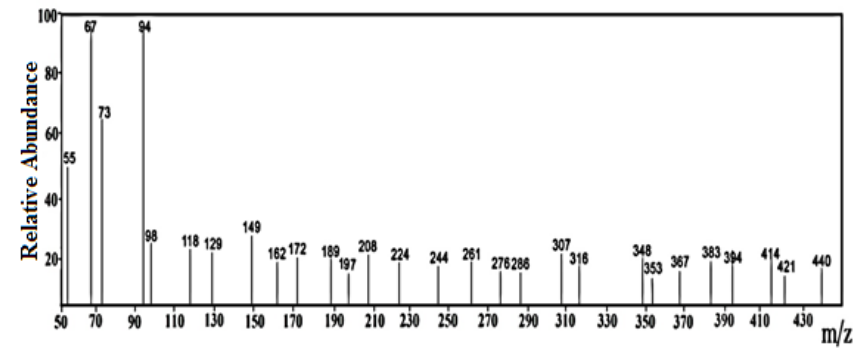

Figure2. The mass spectrum of $\left[\mathrm{Co}(\mathrm{HL})(2-\mathrm{AP}) \mathrm{Cl}_{2}\right] \cdot \mathrm{H}_{2} \mathrm{O}$ complex.

The Mass spectrum of $\left[\mathrm{Ni}(\mathrm{HL})(2-\mathrm{AP}) \mathrm{Cl}_{2}\right] \cdot \mathrm{H}_{2} \mathrm{O}$ complex(Fig. 3)exhibited a molecular ion peak at 440 (Calc.439.9). The existence of both primary and secondary ligands are indicated by the peaks at 199 and 94 (Calc.198.2 and 94.1), respectively. The spectrum exhibits a peak at 421 (Calc.421.9) corresponding to the removal of hydrated water molecule. This fragment ion underwent fragmentation with the loss of the water molecule and two chlorine atoms gave a peak at 353 (351.27).

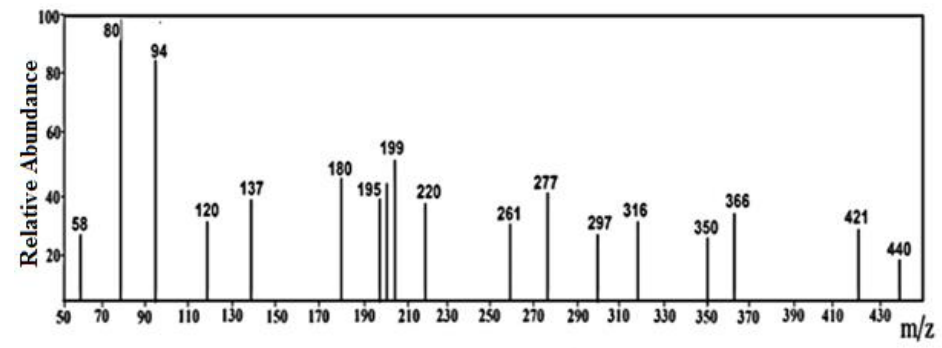

Figure3. The mass spectrum of $\left[\mathrm{Ni}(\mathrm{HL})(2-\mathrm{AP}) \mathrm{Cl}_{2}\right] . \mathrm{H}_{2} \mathrm{O}$ complex.

\subsection{Conductivity Measurements}

The conductance measurements recorded for $10^{-3} \mathrm{M}$ solutions of metal complexes in DMF are listed in Table (1). Cu (II), Ni (II) and Co (II) complexes are non-conducting having conductance values of 10-13 $\Omega^{-1} \mathrm{~mol}^{-1} \mathrm{~cm}^{2}$ indicating their neutrality, so the chloride anion is situated inside the metal coordination sphere. The electrical conductance value of $\mathrm{La}(\mathrm{III})$ chelate is found to have molar conductance value of $87 \mathrm{ohm}^{-1} \mathrm{~mol}^{-1} \mathrm{~cm}^{2}$ indicating its electrolytic nature as 1:1 electrolyte [26]

\subsection{Electronic Spectra and Magnetic Moment Values}

The diffuse reflectance spectra of the HL and the mixed ligand complexes are listed in Table 4. HL showed three bands at 243, 278 and 307 unattributed to $\pi-\pi^{*}, n-\pi^{*}$ and charge transfer transition, respectively. The $\mathrm{Cu}$ (II) complex showed a broad band at $608 \mathrm{~nm}$ assignable to ${ }^{2} \mathrm{E}_{g} \rightarrow{ }^{2} \mathrm{~T}_{2 g}$ transition, which is characteristic of distorted octahedral configuration [27]. The measured value of the magnetic moment lies in the range reported for octahedral complexes (1.95 B.M.). The Ni(II) complex has magnetic moment value of 2.99 B.M., which correspond totwo unpaired electrons about $\mathrm{Ni}$ (II) ion for six-coordinated octahedral geometry [28]. The electronic spectrum of $\mathrm{Ni}(\mathrm{II})$ complex displayed three bands in the solid reflectance spectrum at $v_{1}\left(704 \mathrm{~nm}:{ }^{3} \mathrm{~A}_{2 \mathrm{~g}} \rightarrow{ }^{3} \mathrm{~T}_{2 \mathrm{~g}}\right) ; v_{2}\left(606 \mathrm{~nm}:{ }^{3} \mathrm{~A}_{2 \mathrm{~g}} \rightarrow{ }^{3} \mathrm{~T}_{1 \mathrm{~g}}(\mathrm{~F})\right)$ and $v_{3}$ (476nm: ${ }^{3} \mathrm{~A}_{2 \mathrm{~g}} \rightarrow{ }^{3} \mathrm{~T}_{1 \mathrm{~g}}(\mathrm{P})$ ) [29]. The diffuse reflectance spectrum of the Co(II) complex showed three bands at 473,605 and $734 \mathrm{~nm}$. The bands observed are assigned to the transition ${ }^{4} \mathrm{~T}_{1 \mathrm{~g}}(\mathrm{~F}) \rightarrow{ }^{4} \mathrm{~T}_{1 \mathrm{~g}}(\mathrm{P})$ $\left(v_{3}\right),{ }^{4} \mathrm{~T}_{1 \mathrm{~g}}(\mathrm{~F}) \rightarrow{ }^{4} \mathrm{~A}_{2 \mathrm{~g}}(\mathrm{~F})\left(v_{2}\right)$ and ${ }^{4} \mathrm{~T}_{1 \mathrm{~g}}(\mathrm{~F}) \rightarrow{ }^{2} \mathrm{~T}_{2 \mathrm{~g}}(\mathrm{~F})\left(v_{1}\right)$, respectively, suggesting the octahedral structure around $\mathrm{Co}(\mathrm{II})$ ion [30]. The magnetic moment value of $\mathrm{Co}$ (II) complex has been found to be 4.22 BM corresponding to three unpaired electrons within the range of high spin octahedral complex of $\mathrm{Co}$ (II) ion [31]. The diffuse reflectance spectrum of La (III) $\left(d^{0}\right)$ complex showed $\pi-\pi^{*}$ and $n-\pi^{*}$ bands at 244 and $278 \mathrm{~nm}$, respectively. In addition, another bands displayed in the range 349-384 nm attributed to ligand to metal charge transfer. As expected for the diamagnetic La (III) $\left(\mathrm{d}^{0}\right)$ configuration, ligand field band due to $d-d$ electronic transitions is not expected [32]. 


\subsection{Luminescence Spectral Study}

The fluorescence properties of the Schiff base ligand (HL) and ternary complexes (Fig. 4)were recorded in DMSO at room temperature. The excitation spectrum of the HL ligand showed a maximum emission peak at $430 \mathrm{~nm}$ when excited at $310 \mathrm{~nm}$. Generally, Schiff base systems exhibit fluorescence due to intraligand $\pi \rightarrow \pi^{*}$ transitions. The fluorescent data are summarized in Table 5 . The excitation spectra of $\mathrm{Cu}(\mathrm{II}), \mathrm{Ni}(\mathrm{II}), \mathrm{Co}(\mathrm{II})$ and $\mathrm{La}(\mathrm{III})$ complexes exhibited a strong blue fluorescence emission band in the range 359-364nm when excited at 304-330 nm. Significant differences in the positions of emission maximum of Schiff base and its complexes establish the coordination of the metal ion to the ligand. The fluorescence spectral results reveal that the fluorescence emission intensity of Schiff base increases dramatically on complex formation with transition metal ions. Enhancement of fluorescence through complexation is much interesting as it opens up the opportunity for photochemical applications of these complexes [33].In general, all the synthesized compounds can serve as potential photoactive materials, as indicated from their characteristic fluorescence properties.

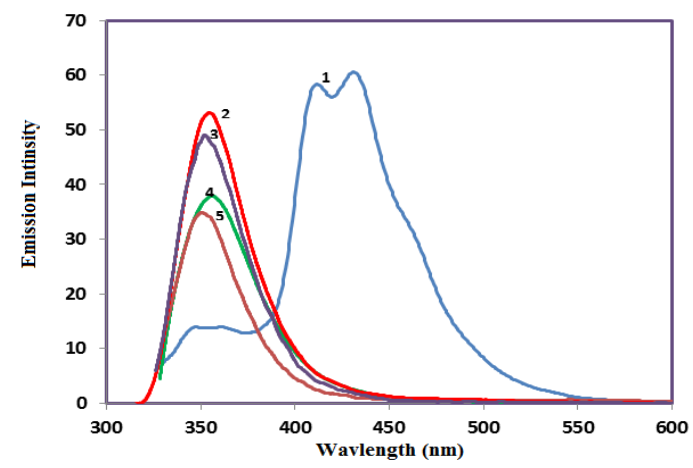

Figure4. Emission spectra of: (1)HL; (2) $\left[\mathrm{Cu}(\mathrm{HL})(2-\mathrm{AP}) \mathrm{Cl}_{2}\right] \cdot \mathrm{H}_{2} \mathrm{O}$; (3) $\quad\left[\mathrm{Ni}(\mathrm{HL})\left(2-\mathrm{AP}^{2} \mathrm{Cl}_{2}\right] \cdot \mathrm{H}_{2} \mathrm{O}\right.$; (4) $\left[\mathrm{Co}(\mathrm{HL})(2-\mathrm{AP}) \mathrm{Cl}_{2}\right] \cdot \mathrm{H}_{2} \mathrm{O}$; (5) [ $\left.\mathrm{La}(\mathrm{HL})(2-\mathrm{AP})\left(\mathrm{NO}_{3}\right)_{2}\right] \cdot \mathrm{NO}_{3}$

\subsection{Thermal Analysis (TGA And Drtga)}

The thermal studies of mixed ligand complexes were carried out using the thermo gravimetric technique (TG) and differential thermo gravimetric (DTG). Table 6gives the detailed thermal decomposition data for complexes.

The TG/DTG curves of $\left[\mathrm{Cu}(\mathrm{HL})(2-\mathrm{AP}) \mathrm{Cl}_{2}\right] \cdot \mathrm{H}_{2} \mathrm{O}$ complex showed three decomposition steps in the range of $31-136^{\circ} \mathrm{C}, 136-493^{\circ} \mathrm{C}$ and $493-744^{\circ} \mathrm{C}$.The first decomposition step due the elimination $\mathrm{ofH}_{2} \mathrm{O}$ with weight loss of $4.16 \%$ (Calc. $4.04 \%$ ). The second decomposition step assigned to the loss of the two chlorine atoms and 2-AP with weight loss of $37.01 \%$ (Calc. $37.09 \%$ ). The third decomposition step could be attributed to the loss of the(HL) ligand with weight loss of $41.06 \%$ (Calc. $40.96 \%$ ) leaving $\mathrm{CuO}$ as residue.

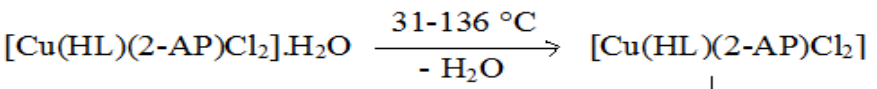

$$
\begin{aligned}
& 136-493{ }^{\circ} \mathrm{C} \\
& \mathrm{CuO} \underset{-\mathrm{HL}}{4} \quad[\mathrm{Cu}(\mathrm{HL})]
\end{aligned}
$$

The TGA curves of $\left[\mathrm{Co}(\mathrm{HL})(2-\mathrm{AP}) \mathrm{Cl}_{2}\right] \cdot \mathrm{H}_{2} \mathrm{O}$ complex showed three decomposition peaks. The first decomposition step occurs in the range $35-144^{\circ} \mathrm{C}$ with mass loss observed is $4.1 \%$ (Calc. $4.28 \%$ ) which attributed to the loss of the $\mathrm{H}_{2} \mathrm{O}$ molecule. The second step of decomposition takes place in the range $144-511^{\circ} \mathrm{C}$ with mass loss $37.24 \%$ (Calc. $37.48 \%$ ) which due to a loss of 2-AP and the two chlorine atoms. The third decomposition step occurs in the range $511-999^{\circ} \mathrm{C}$ with mass loss $40.79 \%$ (Calc. $41.39 \%$ ) which corresponding to the loss of HLleaving $\mathrm{CoO}$ as residue.

$$
\begin{aligned}
& {\left[\mathrm{Co}(\mathrm{HL})(2-\mathrm{AP}) \mathrm{Cl}_{2}\right] \cdot \mathrm{H}_{2} \mathrm{O} \underset{-\mathrm{H}_{2} \mathrm{O}}{\stackrel{35-144}{\circ} \mathrm{C}}\left[\mathrm{Co}(\mathrm{HL})(2-\mathrm{AP}) \mathrm{Cl}_{2}\right]} \\
& 144-511^{\circ} \mathrm{C} \\
& -(2 \mathrm{Cl}+2-\mathrm{AP}) \\
& \mathrm{CoO} \stackrel{511-999^{\circ} \mathrm{C}}{-\mathrm{HL}} \quad[\mathrm{Co}(\mathrm{HL})]
\end{aligned}
$$


The TG plot of $\left[\mathrm{Ni}(\mathrm{HL})(2-\mathrm{AP}) \mathrm{Cl}_{2}\right] \cdot \mathrm{H}_{2} \mathrm{O}$ displayed three decomposition steps. The first step due to the release of the water molecule and the mass loss observed is $4.00 \%$ against the calculated loss of $4.08 \%$ and occurred in the range $33-57^{\circ} \mathrm{C}$. The second step occurred in the range $57-497^{\circ} \mathrm{C}$ with a mass loss of $37.50 \%$ (Calc. $37.50 \%$ ) attributed to the loss of 2-AP and the two chlorine atoms. The third step occurs in the range $497-999^{\circ} \mathrm{C}$ with the mass loss of $42.29 \%$ (Calc. $41.39 \%$ ) which corresponding to a loss of $\mathrm{HL}$ leaving $\mathrm{NiO}$ as residue.

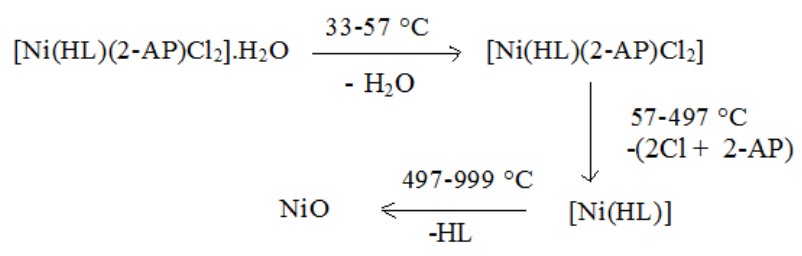

The TGA curves of $\left[\mathrm{La}(\mathrm{HL})(2-\mathrm{AP})\left(\mathrm{NO}_{3}\right)_{2}\right] \cdot \mathrm{NO}_{3}$ complex showed three decomposition steps. The first decomposition step occurred in the range $50-259{ }^{\circ} \mathrm{C}$ with a weight loss of $20.15 \%$ (Calc. $20.09 \%$ ). The percentage loss was consistent with the elimination of the two nitrate groups. The second decomposition stage occurred in the range $259-321{ }^{\circ} \mathrm{C}$ with a weight loss of $10.07 \%$ (Calc. $10.04 \%$ ) could be attributed to the loss of the remaining nitrate group. The third decomposition step occurs in the $321-999^{\circ} \mathrm{C}$ range with a weight loss of $47.42 \%$ (Calc. $47.34 \%$ ) corresponding to loss of the ligands leaving $1 \frac{1}{2} \mathrm{La}_{2} \mathrm{O}_{3}$ as residue.

$$
\begin{aligned}
& {\left[\mathrm{La}(\mathrm{HL})(2-\mathrm{AP})\left(\mathrm{NO}_{3}\right)_{2}\right] \cdot \mathrm{NO}_{3} \underset{-2 \mathrm{NO}_{3}}{\stackrel{50-259^{\circ} \mathrm{C}}{\longrightarrow}}\left[\mathrm{La}(\mathrm{HL})(2-\mathrm{AP}) \mathrm{NO}_{3}\right]}
\end{aligned}
$$

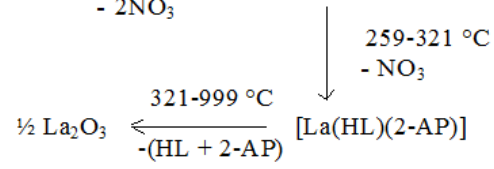

The activation energy $\left(E^{*}\right)$, enthalpy $\left(H^{*}\right)$, entropy $\left(S^{*}\right)$ and Gibbs free energy change of the decomposition $\left(G^{*}\right)$ were evaluated graphically by employing the Coats-Redfern relation [34].

$$
\log \left[\frac{\log \left(W_{\infty} /\left(W_{\infty}-W\right)\right)}{T^{2}}\right]=\log \left[\frac{A R}{\phi E^{*}}\left(1-\frac{2 R T}{E^{*}}\right)\right]-\frac{E^{*}}{2.303 R T}
$$

Where $\mathrm{W}_{\infty}$ is the mass loss at the completion of the decomposition reaction, $\mathrm{W}$ is the mass loss up to temperature $T, R$ is the gas constant and $\phi$ is the heating rate. Since $1-2 R T / E^{*} \cong 1$, the plot of the left-hand side of equation (1) against $1 / \mathrm{T}$ would give a straight line. $\mathrm{E}^{*}$ was then calculated from the slope and the Arrhenius constant, A, was obtained from the intercept. The other kinetic parameters; the entropy of activation ( $\left.\mathrm{S}^{*}\right)$, enthalpy of activation $\left(\mathrm{H}^{*}\right)$ and the free energy change of activation $\left(\mathrm{G}^{*}\right)$ were calculated using the following equations:

$$
\mathrm{H}^{*}=\mathrm{E}^{*}-\mathrm{RT} ; \mathrm{G}^{*}=\mathrm{H}^{*}-\mathrm{TS}^{*} \text { and } \mathrm{S}^{*}=2.303 \mathrm{R} \log \frac{A h}{k T}
$$

Where, (k) and (h) are the Boltzman and Planck constants, respectively. The kinetic parameters are listed in Table 7. From the obtained results, it is apparent that $G^{*}$ values of the complexes acquire highly positive magnitudes. The activation energies of decomposition were found to be in the range $28.5-693.1 \mathrm{KJmol}^{-}$ ${ }^{1}$.The high value of the energy of activation of the complexes revealed the high stability of the investigated complexes due to their covalent character [35]. Additionally, the negative values of entropyindicate that the activated complex has more ordered systems than reactants [36].

In the light of all results, the most reasonable structures of the ternary complexes are shown in Scheme 1.
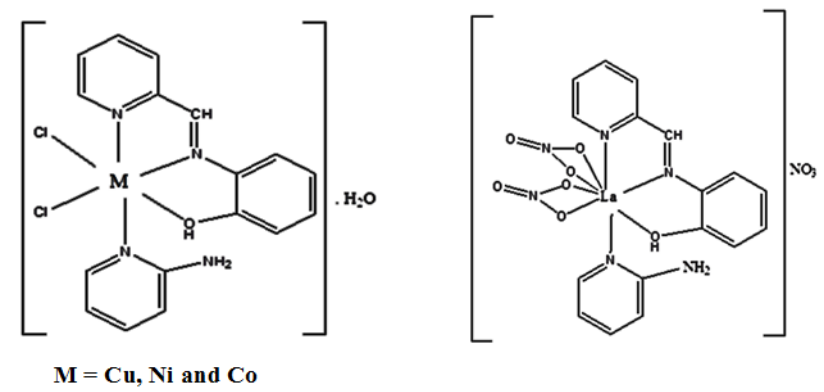

Scheme1. The proposed structure of mixed ligand complexes 


\subsection{Catalytic Activity}

The decomposition of hydrogen peroxide has been used as a model reaction for the investigation of the catalytic activity of various ternary complexes. The decomposition of $\mathrm{H}_{2} \mathrm{O}_{2}$ catalyzed by metal complexes has been monitored by titrating the undecomposed $\mathrm{H}_{2} \mathrm{O}_{2}$ with a standard $\mathrm{KMnO}_{4}$ solution. Variables such as the time were found to have important roles in the decomposition of $\mathrm{H}_{2} \mathrm{O}_{2}$. The effect of time on decomposition of $\mathrm{H}_{2} \mathrm{O}_{2}$ at a constant concentration of $\mathrm{H}_{2} \mathrm{O}_{2}(0.15 \mathrm{~N})$ and constant concentration of complexes $\left(6.4 \times 10^{-3}-9.0 \times 10^{-3} \mathrm{mmol}^{-1}\right)$ at $25^{0} \mathrm{C}$ were studied (Tables8-11).The conditions of catalytic reactions for hydrogen peroxide decomposition were chosen according to the similar studies in the literature [37,38]. The results showed that the percentage of decomposition of hydrogen peroxide increased with the time (Fig. 5). It was observed that $4.5 \mathrm{~h}$ is an adequate reaction time for decomposition of $42.5-72 \%$ of $\mathrm{H}_{2} \mathrm{O}_{2}$ catalyzed by complexes. In the absence of a complex, the percentage of decomposition of hydrogen peroxide occurred spontaneously is $20 \%$ after $24 \mathrm{~h}$. The mechanism of the catalytic reaction has been proposed in the literature [39] is given in formulas (1)(3):

$\mathrm{H}_{2} \mathrm{O}_{2} \rightarrow \mathrm{HO}_{2}^{-}+\mathrm{H}^{+}$

The M-L complex may interact with $\mathrm{HO}_{2}{ }^{-}$ions to form an intermediate complex.

$\mathrm{M}-\mathrm{L}+\mathrm{HO}_{2}^{-} \rightarrow\left[\mathrm{ML}\left(\mathrm{HO}_{2}\right)\right]$

A second molecule of $\mathrm{H}_{2} \mathrm{O}_{2}$ may then interact with the intermediate complex to form the following products.

$\left[\mathrm{ML}\left(\mathrm{HO}_{2}\right)\right]^{-}+\mathrm{H}_{2} \mathrm{O}_{2} \rightarrow \mathrm{M}-\mathrm{L}+\mathrm{H}_{2} \mathrm{O}+\mathrm{OH}^{-}+\mathrm{O}_{2}$

Catalytic decomposition of $\mathrm{H}_{2} \mathrm{O}_{2}$ leads to the formation of intermediate radical species which can bind to the surfaces where $\mathrm{H}_{2} \mathrm{O}_{2}$ undergoes decomposition [40, 41]. The enhanced catalytic activity of the complex system may be explained on the basis of the formation of the above intermediate peroxo species. When a metal complex is bound to a support its motion is restricted. Reactions on such catalysts are expected to be more rapid than one on which the catalyst molecules are free [42].

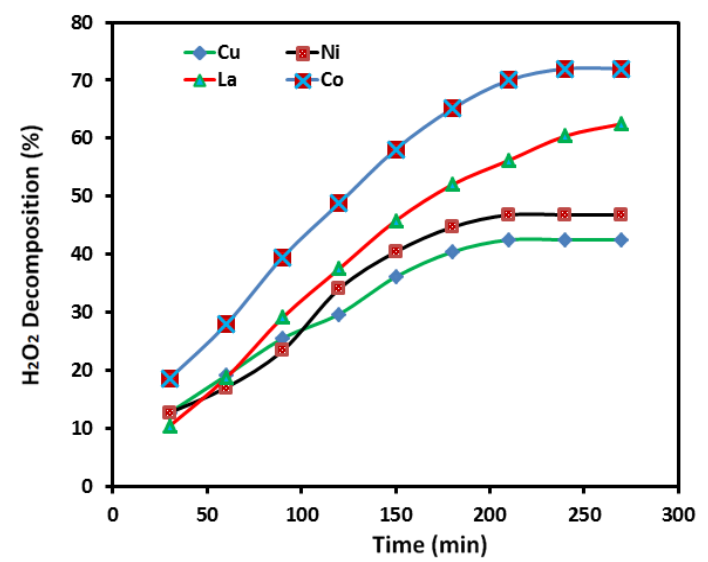

Figure5. Effect of reaction time on decomposition of $\mathrm{H}_{2} \mathrm{O}_{2}$ with $\left[\mathrm{Cu}(\mathrm{HL})(2-\mathrm{AP}) \mathrm{Cl}_{2}\right] \cdot \mathrm{H}_{2} \mathrm{O}, \quad[\mathrm{Co}(\mathrm{HL})(2-$ $\left.\mathrm{AP}) \mathrm{Cl}_{2}\right] \cdot \mathrm{H}_{2} \mathrm{O}$, $\left[\mathrm{Ni}(\mathrm{HL})(2-\mathrm{AP}) \mathrm{Cl}_{2}\right] \cdot \mathrm{H}_{2} \mathrm{O}$ and $\left[\mathrm{La}(\mathrm{HL})(2-\mathrm{AP})\left(\mathrm{NO}_{3}\right)_{2}\right] \cdot \mathrm{NO}_{3}$ complexesat $25^{\circ} \mathrm{C}$.

\subsection{Antibacterial Activity}

Antibacterial activity of Schiff base ligand and ternary complexes have been tested against one gram positive bacteria; $S$. aureus and also against one gram negative bacteria; E.colimicroorganisms. The antibacterial activities obtained for the prepared compounds are listed in Table 12. All the investigated compounds showed a remarkable biological activity against bacteria (Fig. 6). The obtained results reflect that; (1) The ligand, $\mathrm{Cu}(\mathrm{II})$ and $\mathrm{Co}(\mathrm{II})$ complexes possessed moderate activity against $E$. Coli.; (2) $\mathrm{Ni}$ (II) and $\mathrm{La}(\mathrm{III})$ complexes showed lower activity than HL against E. Coli.;(3) All complexes showed higher activity than ligand against $S$. aureus. On chelation, the delocalization of $\pi$ electrons over the whole chelate ring will be increased which enhances the penetration of the complexes into lipid membranes and blocking the metal binding sites in the enzymes of microorganisms. Also, the tested complexes may disturb the respiration process of the cell and consequently block the synthesis of proteins leading to no further growth of the organisms [43]. The variation in the activity values of different compounds against different organisms depends on either the impermeability of the cells of the microbes or on the differences in ribosome of microbial cells [44]. 
Ternary Complexes of Cu (II), Ni (II), Co (II) and La (III) Ions with 2-[(Pyridin-2-Ylmethylidene) Amino] Phenol and Heterocyclic Nitrogen Base

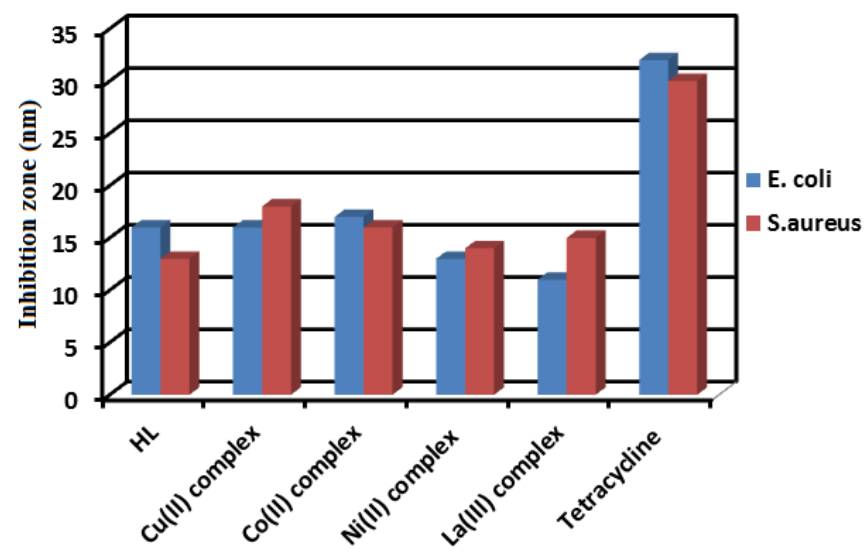

Figure6. Antibacterial activity of compounds under study.

Table1. Analytical and physical data of the Schiff base $(H L)$ and mixed ligand complexes.

\begin{tabular}{|c|c|c|c|c|c|c|c|}
\hline \multirow[t]{2}{*}{ Compound } & \multirow[t]{2}{*}{ M.Wt. } & \multirow[t]{2}{*}{$\begin{array}{l}\text { Color } \\
\text { (\% yield) }\end{array}$} & \multicolumn{3}{|c|}{$\begin{array}{l}\text { Elemental analysis found } \\
\text { (Calc.) }\end{array}$} & \multirow[t]{2}{*}{$\begin{array}{l}\text { M.p. } \\
\left({ }^{\circ} \mathbf{C}\right)\end{array}$} & \multirow{2}{*}{$\begin{array}{l}\mathrm{A}\left(\Omega^{-}\right. \\
{ }^{1} \mathrm{~mol}^{-1} \\
\left.\mathrm{~cm}^{2}\right)\end{array}$} \\
\hline & & & C\% & Н \% & N\% & & \\
\hline $\mathrm{C}_{12} \mathrm{H}_{10} \mathrm{~N}_{2} \mathrm{O}$ & 198.22 & $\begin{array}{l}\text { Dark Yellow } \\
(80)\end{array}$ & $\begin{array}{c}72.11 \\
(72.71)\end{array}$ & $\begin{array}{c}5.21 \\
(5.08)\end{array}$ & $\begin{array}{c}14.22 \\
(14.13)\end{array}$ & 220 & - \\
\hline$\left[\mathrm{Cu}\left(\mathrm{C}_{17} \mathrm{H}_{16} \mathrm{~N}_{4} \mathrm{O}\right) \mathrm{Cl}_{2}\right] \cdot \mathrm{H}_{2} \mathrm{O}$ & 444.80 & $\begin{array}{l}\text { Dark red } \\
(89)\end{array}$ & $\begin{array}{c}45.92 \\
(45.90)\end{array}$ & $\begin{array}{c}4.08 \\
(4.07)\end{array}$ & $\begin{array}{c}12.59 \\
(12.59)\end{array}$ & $>300$ & 10 \\
\hline$\left[\mathrm{Co}\left(\mathrm{C}_{17} \mathrm{H}_{16} \mathrm{~N}_{4} \mathrm{O}\right) \mathrm{Cl}_{2}\right] \cdot \mathrm{H}_{2} \mathrm{O}$ & 440.19 & $\begin{array}{l}\text { Brick red } \\
(87)\end{array}$ & $\begin{array}{c}45.42 \\
(46.38)\end{array}$ & $\begin{array}{c}3.96 \\
(4.12)\end{array}$ & $\begin{array}{c}13 \\
(12.73)\end{array}$ & $>300$ & 13 \\
\hline$\left[\mathrm{Ni}\left(\mathrm{C}_{17} \mathrm{H}_{16} \mathrm{~N}_{4} \mathrm{O}\right) \mathrm{Cl}_{2}\right] \cdot \mathrm{H}_{2} \mathrm{O}$ & 439.97 & $\begin{array}{l}\text { Crimson } \\
(85)\end{array}$ & $\begin{array}{c}46.25 \\
(46.40)\end{array}$ & $\begin{array}{c}4.35 \\
(4.12)\end{array}$ & $\begin{array}{c}12.50 \\
(12.73)\end{array}$ & $>300$ & 12 \\
\hline $\begin{array}{c}\left.\left[\mathrm{La}\left(\mathrm{C}_{17} \mathrm{H}_{16} \mathrm{~N}_{4} \mathrm{O}\right) \mathrm{NO}_{3}\right)_{2}\right] \cdot \mathrm{N} \\
\mathrm{O}_{3}\end{array}$ & 617.26 & Brown (70) & $\begin{array}{c}42.37 \\
(33.08)\end{array}$ & $\begin{array}{c}3.82 \\
(2.61)\end{array}$ & $\begin{array}{c}13.7 \\
(15.88)\end{array}$ & $>300$ & 87 \\
\hline
\end{tabular}

Table2. IR data of the Schiff base (HL) and mixed ligand complexes $\left(\mathrm{cm}^{-1}\right)$.

\begin{tabular}{|c|c|c|c|c|c|c|c|}
\hline \multirow{2}{*}{ Compound } & \multicolumn{7}{|c|}{ IR $\left(\mathrm{cm}^{-1}\right)^{\mathrm{a}}$} \\
\hline & $\begin{array}{c}v(\mathrm{OH}) \text { or } \\
v\left(\mathrm{NH}_{2}\right)\end{array}$ & $v(C=N)$ & v (C-O) & $\delta$ (py) & $\begin{array}{c}\text { v (M- } \\
\text { O) }\end{array}$ & v $(\mathbf{M}-\mathbf{N})$ & Other bands \\
\hline $\mathrm{HL}$ & $3387(b)$ & $\begin{array}{c}1630(\mathrm{w}) \\
1590(\mathrm{~s})\end{array}$ & $1247(\mathrm{~m})$ & $625(w)$ & - & - & - \\
\hline $\begin{array}{c}{[\mathrm{Cu}(\mathrm{HL})(2-} \\
\left.\mathrm{AP}) \mathrm{Cl}_{2}\right] \cdot \mathrm{H}_{2} \mathrm{O}\end{array}$ & $\begin{array}{l}\text { 3321(b) } \\
3403(b)\end{array}$ & $\begin{array}{c}1661(\mathrm{~m}) \\
1626(\mathrm{~s}) \\
1567(\mathrm{~m})\end{array}$ & $1261(\mathrm{~m})$ & $\begin{array}{l}648(w) \\
636(w)\end{array}$ & $549(w)$ & $450(w)$ & - \\
\hline $\begin{array}{l}{[\mathrm{Co}(\mathrm{HL})(2-} \\
\left.\mathrm{AP}) \mathrm{Cl}_{2}\right] \cdot \mathrm{H}_{2} \mathrm{O}\end{array}$ & $\begin{array}{l}\text { 3314(b) } \\
3380(b)\end{array}$ & $\begin{array}{c}1663(\mathrm{~s}) \\
1631(\mathrm{~m}) \\
1593(\mathrm{~m}) \\
\end{array}$ & $1275(\mathrm{~s})$ & $\begin{array}{l}662(w) \\
650(w)\end{array}$ & $550(w)$ & $451(w)$ & - \\
\hline $\begin{array}{c}{[\mathrm{Ni}(\mathrm{HL})(2-} \\
\left.\mathrm{AP}) \mathrm{Cl}_{2}\right] \cdot \mathrm{H}_{2} \mathrm{O}\end{array}$ & 3302(b) & $\begin{array}{c}1662(\mathrm{~s}) \\
1621(\mathrm{~m}) \\
1595(\mathrm{~m})\end{array}$ & $1271(\mathrm{~m})$ & $\begin{array}{l}650(w) \\
612(w)\end{array}$ & $545(w)$ & $425(w)$ & - \\
\hline $\begin{array}{c}{[\mathrm{La}(\mathrm{HL})(2-} \\
\left.\mathrm{AP})\left(\mathrm{NO}_{3}\right)_{2}\right] \cdot \mathrm{NO}_{3}\end{array}$ & 3333(b) & $\begin{array}{c}1664(\mathrm{~s}) \\
1624(\mathrm{w}) \\
1591(\mathrm{~s})\end{array}$ & $1260(\mathrm{sh})$ & $\begin{array}{l}671(w) \\
638(w)\end{array}$ & $547(w)$ & $410(w)$ & $\begin{array}{c}1445(\mathrm{~s}) \\
1034(\mathrm{w}) \\
1311(\mathrm{~m}) \\
818(\mathrm{w})\end{array}$ \\
\hline
\end{tabular}

${ }^{a} m$, medium; s, strong; $w$, weak; sh, shoulder

Table3. ${ }^{1}$ H NMR spectral data of the Schiff base HL and La(III) complex

\begin{tabular}{|c|c|}
\hline Compound & Chemical shift, $\delta(\mathrm{ppm})^{\mathrm{a}}$ \\
\hline $\mathrm{HL}$ & $7.53-7.27 \mathrm{~m}(4 \mathrm{H}$, aromatic $), 8.39-7.92 \mathrm{~m}(4 \mathrm{H}$, pyridine $), 8.59 \mathrm{~s}$ \\
& $(1 \mathrm{H}, \mathrm{HC}=\mathrm{N}), 10.09 \mathrm{~s}(1 \mathrm{H}, \mathrm{OH})$. \\
\hline$\left[\mathrm{La}(\mathrm{HL})(2-\mathrm{AP})\left(\mathrm{NO}_{3}\right)_{2}\right] . \mathrm{NO}_{3}$ & $\begin{array}{c}6.54-6.52 \mathrm{~m}(4 \mathrm{H}, \text { aromatic }), 7.93-7.45 \mathrm{~m}(4 \mathrm{H}, \text { pyridine }), 8.62 \mathrm{~s} \\
(1 \mathrm{H}, \mathrm{HC}=\mathrm{N}), 10.18 \mathrm{~s}(1 \mathrm{H}, \mathrm{OH}) .\end{array}$ \\
\hline
\end{tabular}

${ }^{\mathrm{a}} \mathrm{s}$, singlet; m, multiplet. 
Ternary Complexes of Cu (II), Ni (II), Co (II) and La (III) Ions with 2-[(Pyridin-2-Ylmethylidene) Amino] Phenol and Heterocyclic Nitrogen Base

Table4. The diffuse reflectance data of the Schiff base $(H L)$ and mixed ligand complexes

\begin{tabular}{|c|c|c|c|c|}
\hline \multirow{2}{*}{ Compound } & \multicolumn{3}{|c|}{$\boldsymbol{\lambda}_{\max }(\mathbf{n m})$} \\
\cline { 2 - 5 } & $\pi-\pi^{*}$ & $\mathbf{n}-\pi^{*}$ & Charge transfer & d-d transition \\
\hline $\mathrm{HL}$ & 243 & 278 & 307 & - \\
\hline$\left[\mathrm{Cu}(\mathrm{HL})(2-\mathrm{AP}) \mathrm{Cl}_{2}\right] \cdot \mathrm{H}_{2} \mathrm{O}$ & 255 & 280 & 353 & 608 \\
\hline$\left[\mathrm{Co}(\mathrm{HL})(2-\mathrm{AP}) \mathrm{Cl}_{2}\right] \cdot \mathrm{H}_{2} \mathrm{O}$ & 246 & 269 & 350,384 & $473,605,734$ \\
\hline$\left[\mathrm{Ni}(\mathrm{HL})(2-\mathrm{AP}) \mathrm{Cl}_{2}\right] \cdot \mathrm{H}_{2} \mathrm{O}$ & 244 & 269 & 349,384 & $476,606,704$ \\
\hline$\left[\mathrm{La}(\mathrm{HL})(2-\mathrm{AP})\left(\mathrm{NO}_{3}\right)_{2}\right] \cdot \mathrm{NO}_{3}$ & 244 & 278 & 349,384 & - \\
\hline
\end{tabular}

Table5. Fluorescence data of the Schiff base (HL) and mixed ligand complexes

\begin{tabular}{|c|c|c|}
\hline Compound & $\boldsymbol{\lambda}_{\text {excitation }}$ & $\boldsymbol{\lambda}_{\text {emission }}$ \\
\hline $\mathrm{HL}$ & 310 & $349,410,430$ \\
\hline$\left[\mathrm{Cu}(\mathrm{HL})(2-\mathrm{AP}) \mathrm{Cl}_{2}\right] \cdot \mathrm{H}_{2} \mathrm{O}$ & 304 & 359 \\
\hline$\left[\mathrm{Co}(\mathrm{HL})(2-\mathrm{AP}) \mathrm{Cl}_{2}\right] \cdot \mathrm{H}_{2} \mathrm{O}$ & 318 & 364 \\
\hline$\left[\mathrm{Ni}(\mathrm{HL})(2-\mathrm{AP}) \mathrm{Cl}_{2}\right] \cdot \mathrm{H}_{2} \mathrm{O}$ & 330 & 360 \\
\hline$\left[\mathrm{La}(\mathrm{HL})(2-\mathrm{AP})\left(\mathrm{NO}_{3}\right)_{2}\right] \cdot \mathrm{NO}_{3}$ & 318 & 360 \\
\hline
\end{tabular}

Table6. Thermogravimetric data of mixed ligand complexes.

\begin{tabular}{|c|c|c|c|c|c|}
\hline \multirow{2}{*}{ Complex } & \multirow{2}{*}{$\begin{array}{c}\text { TG range } \\
\left({ }^{\circ} \mathbf{C}\right)\end{array}$} & \multicolumn{2}{|c|}{ Mass loss \% } & Assignment & \multirow{2}{*}{$\begin{array}{c}\text { Metallic residue } \\
\text { Calc. (found) }\end{array}$} \\
\cline { 2 - 5 } & & Calc. & Found & & \\
\hline$\left[\mathrm{Cu}(\mathrm{HL})(2-\mathrm{AP}) \mathrm{Cl}_{2}\right] \cdot \mathrm{H}_{2} \mathrm{O}$ & $31-136$ & 4.05 & 4.16 & Loss of $\mathrm{H}_{2} \mathrm{O}$ & $\mathrm{CuO} 17.88 \%$ \\
& $136-493$ & 37.11 & 37.01 & Loss of $2 \mathrm{Cl}+2-$ & $(17.77 \%)$ \\
& $493-744$ & 40.96 & 41.06 & $\mathrm{AP}$ & \\
\hline$\left[\mathrm{Co}(\mathrm{HL})(2-\mathrm{AP}) \mathrm{Cl}_{2}\right] \cdot \mathrm{H}_{2} \mathrm{O}$ & $35-144$ & 4.10 & 4.28 & Loss of $\mathrm{H}_{2} \mathrm{O}$ & $\mathrm{CoO} 17.03 \%$ \\
& $144-511$ & 37.48 & 37.24 & Loss of $2 \mathrm{Cl}+2-\mathrm{AP}$ & $(17.69 \%)$ \\
& $511-999$ & 41.39 & 40.79 & Loss of $(\mathrm{HL})$ & \\
\hline$\left[\left[\mathrm{Ni}(\mathrm{HL})(2-\mathrm{AP}) \mathrm{Cl}_{2}\right] \cdot \mathrm{H}_{2} \mathrm{O}\right.$ & $33-57$ & 4.09 & 4.00 & Loss of $\mathrm{H}_{2} \mathrm{O}$ & $\mathrm{NiO} 16.99 \%$ \\
& $57-497$ & 37.51 & 37.70 & Loss of $2 \mathrm{Cl}+2 \mathrm{AP}$ & $(17.01 \%)$ \\
& $497-999$ & 41.41 & 41.29 & Loss of $(\mathrm{HL})$ & \\
\hline$\left[\mathrm{La}(\mathrm{HL})(2 \mathrm{AP})\left(\mathrm{NO}_{3}\right)_{2}\right] \cdot \mathrm{NO}_{3}$ & $50-259$ & 20.09 & 20.15 & Loss of $2 \mathrm{NO}_{3}$ & $1 / 2 \mathrm{La}_{2} \mathrm{O}_{3} 26.40 \%$ \\
& $259-321$ & 10.04 & 10.07 & Loss of $\mathrm{NO}_{3}$ & $(26.52 \%)$ \\
& $321-999$ & 43.47 & 43.18 & Loss of $\left(2 \mathrm{AP}^{2} \mathrm{HL}\right)$ & \\
\hline
\end{tabular}

Table7. Thermodynamic data of the thermal decompositions steps of mixed ligand complexes

\begin{tabular}{|c|c|c|c|c|c|c|}
\hline Complex & $\begin{array}{c}\text { Decomposition } \\
\text { range }\left(^{\circ} \mathbf{C}\right)\end{array}$ & $\begin{array}{c}\mathbf{E}^{*} / \mathbf{k J m o l} \\
\mathbf{1}\end{array}$ & $\mathbf{A}\left(\mathbf{S}^{-1}\right)$ & $\begin{array}{c}\mathbf{S}^{*} / \mathbf{K}^{-} \\
\mathbf{1} \mathbf{J m o l}^{-1}\end{array}$ & $\begin{array}{c}\mathbf{H}^{*} / \mathbf{k J m o l} \\
\mathbf{1}\end{array}$ & $\begin{array}{c}\mathbf{G}^{*} / \mathbf{k J m o l} \\
\mathbf{1}\end{array}$ \\
\hline$[\mathrm{Cu}(\mathrm{HL})(2-$ & $136-298$ & 42.52 & $2.3 \times 10^{3}$ & -178.17 & 40.66 & 80.39 \\
$\left.\mathrm{AP}) \mathrm{Cl}_{2}\right] . \mathrm{H}_{2} \mathrm{O}$ & $466-715$ & 68.13 & $3.8 \times 10^{2}$ & -202.56 & 62.29 & 204.44 \\
\hline$[\mathrm{Co}(\mathrm{HL})(2-$ & $79-330$ & 28.55 & $3.8 \times 10^{1}$ & -214.47 & 26.09 & 89.30 \\
$\left.\mathrm{AP}) \mathrm{Cl}_{2}\right] . \mathrm{H}_{2} \mathrm{O}$ & $414-664$ & 63.65 & $5.6 \times 10^{2}$ & -198.17 & 58.61 & 178.62 \\
& $709-801$ & 374.19 & $2.3 \times 10^{7}$ & -379.80 & 367.70 & 663.39 \\
& $802-886$ & 693.13 & $2.7 \times 10^{20}$ & -628.00 & 686.02 & 120.99 \\
\hline$[[\mathrm{Ni}(\mathrm{HL})(2-$ & $33-109$ & 39.51 & $1.8 \times 10^{5}$ & -129.50 & 388.98 & 45.38 \\
$\left.\mathrm{AP}) \mathrm{Cl}_{2}\right] . \mathrm{H}_{2} \mathrm{O}$ & $113-347$ & 42.86 & $1.2 \times 10^{3}$ & -183.29 & 41.04 & 81.09 \\
& $432-747$ & 65.53 & $4.9 \times 10^{2}$ & -198.59 & 60.29 & 170.96 \\
\hline$[\mathrm{La}(\mathrm{HL})(2-$ & $92-249$ & 30.89 & $1.89 \times 10^{2}$ & -199.22 & 28.98 & 74.76 \\
$\left.\mathrm{AP})\left(\mathrm{NO}_{3}\right)_{2}\right] . \mathrm{NO}_{3}$ & $250-345$ & 108.45 & $1.05 \times 10^{9}$ & -72.41 & 106.0 & 128.06 \\
& $385-543$ & 150.47 & $4.4 \times 10^{9}$ & -63.94 & 146.57 & 176.54 \\
\hline
\end{tabular}

Table8. Effect of time on decomposition of $\mathrm{H}_{2} \mathrm{O}_{2}$ at constant concentration of $\mathrm{H}_{2} \mathrm{O}_{2}(0.15 \mathrm{~N})$ and $\mathrm{Cu}(\mathrm{II})$ complex $\left(7.6 \times 10^{-3} \mathrm{mmol}\right)$ at $25^{\circ} \mathrm{C}$.

\begin{tabular}{|c|c|c|c|c|c|c|c|c|c|}
\hline & \multicolumn{9}{c|}{ Time (Minutes) } \\
\cline { 2 - 10 } & $\mathbf{3 0}$ & $\mathbf{6 0}$ & $\mathbf{9 0}$ & $\mathbf{1 2 0}$ & $\mathbf{1 5 0}$ & $\mathbf{1 8 0}$ & $\mathbf{2 1 0}$ & $\mathbf{2 4 0}$ & $\mathbf{2 7 0}$ \\
\hline $\begin{array}{c}\text { Baseline } \mathrm{KMnO}_{4} \\
\text { (a) }\end{array}$ & $4.7 \mathrm{~mL}$ & $4.7 \mathrm{~mL}$ & 4.7 & 4.7 & $4.7 \mathrm{~mL}$ & 4.7 & $4.7 \mathrm{~mL}$ & 4.7 & 4.7 \\
& & & $\mathrm{~mL}$ & $\mathrm{~mL}$ & & $\mathrm{~mL}$ & & $\mathrm{~mL}$ & $\mathrm{~mL}$ \\
\hline Volume of $\mathrm{KMnO}_{4}$ & $4.1 \mathrm{~mL}$ & $3.8 \mathrm{~mL}$ & 3.5 & 3.3 & $3.0 \mathrm{~mL}$ & 2.8 & $2.7 \mathrm{~mL}$ & 2.7 & 2.7 \\
\hline
\end{tabular}


Ternary Complexes of Cu (II), Ni (II), Co (II) and La (III) Ions with 2-[(Pyridin-2-Ylmethylidene) Amino] Phenol and Heterocyclic Nitrogen Base

\begin{tabular}{|c|c|c|c|c|c|c|c|c|c|}
\hline$(\mathrm{x})$ & & & $\mathrm{mL}$ & $\mathrm{mL}$ & & $\mathrm{mL}$ & & $\mathrm{mL}$ & $\mathrm{mL}$ \\
\hline $\begin{array}{c}\text { Volume of } \mathrm{H}_{2} \mathrm{O}_{2} \\
\text { decomposed }(\mathrm{a}-\mathrm{x})\end{array}$ & $0.6 \mathrm{~mL}$ & $0.9 \mathrm{~mL}$ & $\begin{array}{c}1.2 \\
\mathrm{~mL}\end{array}$ & $\begin{array}{c}1.4 \\
\mathrm{~mL}\end{array}$ & $1.7 \mathrm{~mL}$ & $\begin{array}{c}1.9 \\
\mathrm{~mL}\end{array}$ & $2.0 \mathrm{~mL}$ & $\begin{array}{c}2.0 \\
\mathrm{~mL}\end{array}$ & $\begin{array}{c}2.0 \\
\mathrm{~mL}\end{array}$ \\
\hline $\begin{array}{c}\% \text { of } \mathrm{H}_{2} \mathrm{O}_{2} \\
\text { decomposed(ax)/(a) }\end{array}$ & 12.7 & 19.1 & 25.5 & 29.7 & 36.1 & 40.4 & 42.5 & 42.5 & 42.5 \\
\hline
\end{tabular}

Table9. Effect of time on decomposition of $\mathrm{H} 2 \mathrm{O} 2$ at constant concentration of $\mathrm{H} 2 \mathrm{O} 2(0.15 \mathrm{~N})$ and $\mathrm{Co}(\mathrm{II})$ complex $(6.8 \times 10-3 \mathrm{mmol})$ at 25 oC.

\begin{tabular}{|c|c|c|c|c|c|c|c|c|c|}
\hline & \multicolumn{9}{|c|}{ Time (Minutes) } \\
\hline & 30 & 60 & 90 & 120 & 150 & 180 & 210 & 240 & 270 \\
\hline $\begin{array}{l}\text { Baseline } \mathrm{KMnO}_{4} \\
\text { (a) }\end{array}$ & $\begin{array}{l}4.3 \\
\mathrm{~mL}\end{array}$ & $\begin{array}{l}4.3 \\
\mathrm{~mL}\end{array}$ & $4.3 \mathrm{~mL}$ & $\begin{array}{l}4.3 \\
\mathrm{~mL}\end{array}$ & $4.3 \mathrm{~mL}$ & $4.3 \mathrm{~mL}$ & $4.3 \mathrm{~mL}$ & $\begin{array}{l}4.3 \\
\mathrm{~mL}\end{array}$ & $4.3 \mathrm{~mL}$ \\
\hline $\begin{array}{l}\text { Volume of } \mathrm{KMnO}_{4} \\
(\mathrm{x})\end{array}$ & $\begin{array}{l}3.5 \\
\mathrm{~mL}\end{array}$ & $\begin{array}{l}3.1 \\
\mathrm{~mL}\end{array}$ & $2.6 \mathrm{~mL}$ & $\begin{array}{l}2.2 \\
\mathrm{~mL}\end{array}$ & $1.8 \mathrm{~mL}$ & $1.5 \mathrm{~mL}$ & $1.3 \mathrm{~mL}$ & $\begin{array}{l}1.2 \\
\mathrm{~mL}\end{array}$ & $1.2 \mathrm{~mL}$ \\
\hline $\begin{array}{l}\text { Volume of } \mathrm{H}_{2} \mathrm{O}_{2} \\
\text { decomposed (a-x) }\end{array}$ & $\begin{array}{l}0.8 \\
\mathrm{~mL}\end{array}$ & $\begin{array}{l}1.2 \\
\mathrm{~mL}\end{array}$ & $1.7 \mathrm{~mL}$ & $\begin{array}{l}2.1 \\
\mathrm{~mL}\end{array}$ & $2.5 \mathrm{~mL}$ & $2.8 \mathrm{~mL}$ & $3.0 \mathrm{~mL}$ & $\begin{array}{l}3.1 \\
\mathrm{~mL}\end{array}$ & $3.1 \mathrm{~mL}$ \\
\hline $\begin{array}{c}\% \text { of } \mathrm{H}_{2} \mathrm{O}_{2} \\
\text { decomposed(ax)/(a) }\end{array}$ & 18.6 & 27.9 & 39.5 & 48.8 & 58.1 & 65.1 & 70 & 72 & 72 \\
\hline
\end{tabular}

Table10. Effect of time on decomposition of $\mathrm{H}_{2} \mathrm{O}_{2}$ at constant concentration of $\mathrm{H}_{2} \mathrm{O}_{2}(0.15 \mathrm{~N})$ and $\mathrm{Ni}(\mathrm{II})$ complex $\left(9.0 \times 10^{-3} \mathrm{mmol}\right)$ at $25^{\circ} \mathrm{C}$.

\begin{tabular}{|c|c|c|c|c|c|c|c|c|c|}
\hline & \multicolumn{9}{|c|}{ Time (Minutes) } \\
\hline & 30 & 60 & 90 & 120 & 150 & 180 & 210 & 240 & 270 \\
\hline $\begin{array}{l}\text { Baseline } \mathrm{KMnO}_{4} \\
\text { (a) }\end{array}$ & $\begin{array}{l}4.7 \\
\mathrm{~mL}\end{array}$ & $\begin{array}{l}4.7 \\
\mathrm{~mL}\end{array}$ & $\begin{array}{l}4.7 \\
\mathrm{~mL}\end{array}$ & $4.7 \mathrm{~mL}$ & $\begin{array}{l}4.7 \\
\mathrm{~mL}\end{array}$ & $\begin{array}{l}4.7 \\
\mathrm{~mL}\end{array}$ & $\begin{array}{l}4.7 \\
\mathrm{~mL}\end{array}$ & $4.7 \mathrm{~mL}$ & $4.7 \mathrm{~mL}$ \\
\hline $\begin{array}{l}\text { volume of } \mathrm{KMnO}_{4} \\
\text { (x) }\end{array}$ & $\begin{array}{l}4.1 \\
\mathrm{~mL}\end{array}$ & $\begin{array}{l}3.9 \\
\mathrm{~mL}\end{array}$ & $\begin{array}{l}3.6 \\
\mathrm{~mL}\end{array}$ & $3.1 \mathrm{~mL}$ & $\begin{array}{l}2.8 \\
\mathrm{~mL}\end{array}$ & $\begin{array}{l}2.6 \\
\mathrm{~mL}\end{array}$ & $\begin{array}{l}2.2 \\
\mathrm{~mL}\end{array}$ & $2.2 \mathrm{~mL}$ & $2.2 \mathrm{~mL}$ \\
\hline $\begin{array}{c}\text { Volume of } \mathrm{H}_{2} \mathrm{O}_{2} \\
\text { decomposed }(\mathrm{a}-\mathrm{x})\end{array}$ & $\begin{array}{l}0.6 \\
\mathrm{~mL}\end{array}$ & $\begin{array}{l}0.8 \\
\mathrm{~mL}\end{array}$ & $\begin{array}{l}1.1 \\
\mathrm{~mL}\end{array}$ & $1.6 \mathrm{~mL}$ & $\begin{array}{l}1.9 \\
\mathrm{~mL}\end{array}$ & $\begin{array}{l}2.1 \\
\mathrm{~mL}\end{array}$ & $\begin{array}{l}3.0 \\
\mathrm{~mL}\end{array}$ & $3.1 \mathrm{~mL}$ & $3.1 \mathrm{~mL}$ \\
\hline $\begin{array}{c}\% \text { of } \mathrm{H}_{2} \mathrm{O}_{2} \\
\text { decomposed (a- } \\
x) /(a)\end{array}$ & 12.7 & 17 & 23.4 & 34 & 40.4 & 44.6 & 46.8 & 46.8 & 46.8 \\
\hline
\end{tabular}

Table11. Effect of time on decomposition of $\mathrm{H}_{2} \mathrm{O}_{2}$ at constant concentration of $\mathrm{H}_{2} \mathrm{O}_{2}(0.15 \mathrm{~N})$ and La(III) complex $\left(6.4 \times 10^{-3} \mathrm{mmol}\right)$ at $25^{\circ} \mathrm{C}$.

\begin{tabular}{|c|c|c|c|c|c|c|c|c|c|}
\hline & \multicolumn{9}{|c|}{ Time (Minutes) } \\
\cline { 2 - 10 } & $\mathbf{3 0}$ & $\mathbf{6 0}$ & $\mathbf{9 0}$ & $\mathbf{1 2 0}$ & $\mathbf{1 5 0}$ & $\mathbf{1 8 0}$ & $\mathbf{2 1 0}$ & $\mathbf{2 4 0}$ & $\mathbf{2 7 0}$ \\
\hline $\begin{array}{c}\text { Baseline } \mathrm{KMnO}_{4} \\
(\mathrm{a})\end{array}$ & $\begin{array}{l}4.8 \\
\mathrm{~mL}\end{array}$ & $\begin{array}{l}4.8 \\
\mathrm{~mL}\end{array}$ & $4.8 \mathrm{~mL}$ & $4.8 \mathrm{~mL}$ & $4.8 \mathrm{~mL}$ & 4.8 & $4.8 \mathrm{~mL}$ & $4.8 \mathrm{~mL}$ & $\begin{array}{c}4.8 \\
\mathrm{~mL}\end{array}$ \\
\hline $\begin{array}{c}\text { volume of } \mathrm{KMnO}_{4} \\
(\mathrm{x})\end{array}$ & $\begin{array}{l}4.3 \\
\mathrm{~mL}\end{array}$ & $\begin{array}{l}3.9 \\
\mathrm{~mL}\end{array}$ & $3.4 \mathrm{~mL}$ & $3.0 \mathrm{~mL}$ & $2.6 \mathrm{~mL}$ & 2.3 & $2.1 \mathrm{~mL}$ & $1.9 \mathrm{~mL}$ & 1.8 \\
$\mathrm{~mL}$ & & & & & & $\mathrm{~mL}$ \\
\hline Volume of $\mathrm{H}_{2} \mathrm{O}_{2}$ & 0.5 & 0.9 & $1.4 \mathrm{~mL}$ & $1.8 \mathrm{~mL}$ & $2.2 \mathrm{~mL}$ & 2.5 & $2.7 \mathrm{~mL}$ & $2.9 \mathrm{~mL}$ & 3.0 \\
decomposed $(\mathrm{a}-\mathrm{x})$ & $\mathrm{mL}$ & $\mathrm{mL}$ & & & & $\mathrm{mL}$ & & & $\mathrm{mL}$ \\
\hline $\begin{array}{c}\text { \% of } \mathrm{H}_{2} \mathrm{O}_{2} \\
\text { decomposed(ax)/(a) }\end{array}$ & 10.4 & 18.7 & 29.1 & 37.7 & 45.8 & 52 & 56.2 & 60.4 & 62.5 \\
\hline
\end{tabular}

Table12. Biological activities of ligand $(H L)$ and mixed ligand complexes

\begin{tabular}{|c|c|c|}
\hline \multirow[b]{2}{*}{ Compound } & \multicolumn{2}{|c|}{ Diameter of inhibition zone (mm) } \\
\hline & Escherichia coli (G-) & Staphylococcus Aureus (G+) \\
\hline HL & 16 & 13 \\
\hline$\left[\mathrm{Cu}(\mathrm{HL})(2-\mathrm{AP}) \mathrm{Cl}_{2}\right] \cdot \mathrm{H}_{2} \mathrm{O}$ & 16 & 18 \\
\hline$\left[\mathrm{Co}(\mathrm{HL})(2-\mathrm{AP}) \mathrm{Cl}_{2}\right] \cdot \mathrm{H}_{2} \mathrm{O}$ & 17 & 16 \\
\hline$\left[\mathrm{Ni}(\mathrm{HL})(2-\mathrm{AP}) \mathrm{Cl}_{2}\right] \cdot \mathrm{H}_{2} \mathrm{O}$ & 13 & 14 \\
\hline$\left[\mathrm{La}(\mathrm{HL})(2-\mathrm{AP})\left(\mathrm{NO}_{3}\right)_{2}\right] \cdot \mathrm{NO}_{3}$ & 11 & 15 \\
\hline Tetracycline Antibacterial agent & 32 & 30 \\
\hline
\end{tabular}

\section{Conclusion}

The mixed ligand complexes are formed in the 1:1:1 ratio as found from the elemental analyses and found to have the formulae $\left[\mathrm{M}(\mathrm{HL})(2-\mathrm{AP}) \mathrm{Cl}_{2}\right] \cdot \mathrm{H}_{2} \mathrm{O}$ and $\left[\mathrm{La}(\mathrm{HL})(2-\mathrm{AP})\left(\mathrm{NO}_{3}\right)_{2}\right] \cdot \mathrm{NO}_{3}$ where $\mathrm{M}=\mathrm{Cu}(\mathrm{II})$, 
$\mathrm{Ni}(\mathrm{II})$ and $\mathrm{Co}(\mathrm{II})$ ions, 2-AP $=2$-aminopyridine and $\mathrm{HL}=2$-[(pyridin-2-ylmethylidene)amino $]$ phenol. The molar conductance data reveal that the chelates are non-electrolytes except $\mathrm{La}$ (III) complex. The thermal complexes stability investigations enable to evaluate the assumed position of water molecules in the outer or inner sphere of the coordination, to know the mechanism of complex decomposition. The activation thermodynamic parameters, such as, $\mathrm{E}^{*}, \mathrm{H}^{*}, \mathrm{~S}^{*}$ and $\mathrm{G}^{*}$ are calculated from the TG curves and discussed. The catalytic activities of the complexes towards hydrogen peroxide decomposition reaction were investigated. The biological activity studies show the possibility to use some of the synthesized compounds as antibacterial agents.

\section{REFERENCES}

[1] Scott, N.M., Schareina, T., Tok, O., Kempe, R., Eur. J. Inorg. Chem. 2004 (2004) 3297.

[2] Poola, B., Choung, W., Nantz, M.H., Tetrahedron 64 (2008) 10798.

[3] Yalcın, B., Fatullayeva, P.A., Buyukgungor, O., Kosar, B., Tascioglu, S., Israfilov, A.I. , Ibayev, Z.D., Medjidov, A.A., Aydın, A., Polyhedron 26 (2007) 3301.

[4] Yenikaya,C., Poyraz,M., Sarı,M., Demirci,F., İlkimen,H., Büyükgüngör,O., Polyhedron 28 (2009) 3526.

[5] Amr, A.G., Mohamed, A.M., Mohamed, S.F., Abdel-Hafez, N.A., Hammam, A. Bioorg. Med. Chem., 14 (2006) 5481.

[6] Zhuravel, I.O., Kovalenko, S.M., Ivachtchenko, A.V., Balakin, K.V., Kazmirchuk, V., Bioorg. Med. Chem. Lett., 5 (2005) 5483.

[7] Goel, A., Ram, V.J., Tetrahedron 65 (2009) 7865.

[8] Al-Hashimy, N.A., Hussein,Y.A., Spectrochim. Acta A 75 (2010) 198.

[9] Travnicek, Z., Mikulík, J., Cajan, M., Zboril, R., Popa, I., Bioorg Med Chem 16 (2008) 8719.

[10] McKee, M.L., Kerwin, S.M., Bioorg Med Chem 16 (2008) 1775.

[11] Khoo, T.J., Break, M.K.b., Crouse, K.A., Tahir, M.I.M., Ali, A.M., Cowley, A.R., Watkin, D.J., Tarafder, M.T.H., InorganicaChimicaActa 413 (2014) 68.

[12] Ali, O.A.M., El-Medani, S.M., Ahmed, D.A., Nassar, D.A., Journal of Molecular Structure 1074 (2014) 713.

[13] La Durantaye, L.D., McCormick, T., Jia, W.L., Wang, S., Dalton Trans. (2006) 5675.

[14] Lin, H.C., Huang, C.C., Shi, C.H., Liao, Y.H., Chen, C.C., Lin, Y.C., Liu, Y.H., Dalton Trans. (2007) 781.

[15] Basak, S., Sen, S.,Banerjee, S.,Mitra, S., Rosair, G.,Rodriguez, M.T.G.,polyhedron 26 (2007) 5104.

[16] Shebl, M., Spectrochim. Acta (A) 117 (2014) 127.

[17] Gomathi, V., Selvameena, R., International Journal of Scientific Research 2 (2013) 24.

[18] Gupta, K.C., Abdulkadir, H.K., J. of Macromolecular Sci. A 45 (2008) 53.

[19] Demetgul, C., Carbohydrate Polymers 89 (2012) 354.

[20] Hosny, N.M., Trans. Met. Chem., 32 (2007) 117.

[21] Gudasi, K.B., Patil, S.A., Vadavi, R.S., Shenoy, R.V, Patil, M.S., J. Transition Met. Chem., 30 (2005) 726.

[22] Shebl, M., Spectrochim. Acta A 70 (2008) 850.

[23] Taha, Z.A., Ajlouni, A.M., Al Momani, W., J. of Luminescence 132 (2012) 2832.

[24] Jadhav, S.M., Shelke, V.A., Shankarwar, S.G., Munde, A.S., Chandrashekar, T.K., J. Saudi Chem. Soc. (2011) doi:10.1016.

[25] Naik, K.H.K., Selvaraj, S., Naik, N., Spectrochim. Acta A 131( 2014) 599.

[26] Abd El-Wahab, Z.H., J.Coord.Chem. 61 (2008)3284.

[27] Reiss, A., Florea, S., Caproiu, T., Stanica, N., Turk J. Chem. 33 (2009) 775.

[28] Lever, A.B.P., Electronic Spectra of $\mathrm{d}^{\mathrm{n}}$ Ions in Inorganic Electronic Spectroscopy, second ed., Elsevier, Amsterdam, The Netherlands, 1984.

[29] Mohamed, G.G., Omar, M.M., Hindy, A.M.M., J. Spectrochim. Acta A 62 (2005) 1140.

[30] Mohamed, G.G., Abd El-Wahab, Z.H., J. Spectrochim. Acta A 61 (2005) 1059.

[31] Abd El-Wahab, Z.H., Mashaly, M.M., Salman, A.A., El-Shetary, B.A., Faheim, A.A., J. Spectrochim.Acta (A) 60 (2004) 2861.

[32] Ali, O.A.M., Spectrochim. Acta (A) 121 (2014) 188.

[33] Majumder, A., Rosair, G.M., Mallick, A., Chattopadhyay, N., Mitra, S., J. Polyhedron 25 (2006) 1753.

[34] Coats, A.W., Redfern, J.P., Nature 20 (1964) 68.

[35] Taakeyama, T., Quinn, F., Thermal Analysis, Fundamentals and Applications to Polymer Science, John Wiley and Sons, Chichester, 1994. 
Ternary Complexes of Cu (II), Ni (II), Co (II) and La (III) Ions with 2-[(Pyridin-2-Ylmethylidene) Amino] Phenol and Heterocyclic Nitrogen Base

[36] Frost, A.A., Pearson, R.G., Kinetics and Mechanisms, Wiley, New York, 1961.

[37] Hosny, N.M., Trans. Met. Chem. 32 (2007) 117.

[38] Gupta, K.C., Abdulkadir, H.K., J. of Macromolecular Sci. A 45 (2007) 53.

[39] Demetgul, C., Carbohydrate Polymers 89 (2012) 354.

[40] Lousada, C.M., Jonsson, M., J. Phys. Chem. 114 (2010) 11202.

[41] Zigah, D., Lopez, J.R., Bard, A., J. Phys. Chem. 14 (2012) 12764.

[42] Chithra, P.G., Nisha, J.T., Beena, B., Indian Journal of Chemical Technology 16 (2009) 188.

[43] Dharmaraj, N., Viswanathamurthi, P., Nataragan, K., J. Transition Met. Chem. 26 (2001) 105.

[44] Garg, R., Fahmi, N., Singh, R.V., Russian Journal of Coordination Chemistry 33 (2007) 761.

Citation: Omyma A. M. Ali, et.al, "Ternary Complexes of Cu(II), Ni(II), Co(II) And La(III) Ions with 2[(Pyridin-2- Ylmethylidene) Amino]Phenol and Heterocyclic Nitrogen Base", International Journal of Advanced Research in Chemical Science, vol. 6, no. 8, p. 21-32, 2019. DOI: http://dx.doi.org/10.20431/23490403.0608004

Copyright: (c) 2019 Authors. This is an open-access article distributed under the terms of the Creative Commons Attribution License, which permits unrestricted use, distribution, and reproduction in any medium, provided the original author and source are credited. 